International Research Journal of Management, IT \& Social Sciences
Available online at https://sloap.org/journals/index.php/irjmis/
Vol. 8 No. 1, January 2021, pages: 110-122
ISSN: 2395-7492
https://doi.org/10.21744/irjmis.v8n1.1140

\title{
Examining Recruitment Strategies and Millennial Employee Selection
}

Ida Ayu Pradnyani Utami Manuaba ${ }^{a}$ Gede Sri Darma ${ }^{b}$

Article history:

Submitted: 27 November 2020

Revised: 18 December 2020

Accepted: 09 January 2021

\section{Keywords:}

millennial; recruitment; selection; strategy; workplace expectations;

\begin{abstract}
The purpose of this study is to look for concrete forms of millennial recruitment and selection strategies. Besides, the purpose of this study is to invite the readers of this study to see what obstacles occur in the strategy of recruitment and selection of Millennial employees. This research was conducted at PT. BPR Lestari Bali. Design This study uses a qualitative approach with descriptive analysis methods. The sample used in this study is based on a purposive sampling technique, namely the determination of samples based on the suitability of certain characteristics and criteria. Data collection techniques used are through observation, interviews, and documentation. The results of this study are to look for concrete forms of recruitment and selection strategies for millennial employees. The actual form of recruitment strategy consists of recruitment preparation, dissemination of job vacancies online, acceptance of applications, and through the Internship program. The results of research on the process of implementing the recruitment and selection strategy at PT. BPR Lestari Bali has been implemented well by the company. Several theories have been applied so that there are not many obstacles or obstacles in the implementation of millennial recruitment and selection strategies.
\end{abstract}

International research journal of management, IT and social sciences (C) 2021. This is an open access article under the CC BY-NC-ND license (https://creativecommons.org/licenses/by-nc-nd/4.0/).

Corresponding author:

Ida Ayu Pradnyani Utami Manuaba,

Human Capital Management, Undiknas Graduate School, Indonesia.

Email address: dindapradnyani23@gmail.com

${ }^{a}$ Human Capital Management, Undiknas Graduate School, Indonesia

Director and Professor of Undiknas Graduate School, Indonesia 


\section{Introduction}

Recently, there have been many opinions about who the "Millennial Generation" is, what they think and value, and how they will behave as they get older and gain more experience in the world of work (DiBiase et al., 2010). The term Millennial denotes people who were born between the early 1980s and early 2000s (Koe et al., 2012), making them the youngest generation in the actual job market. In 2015, this generation increased dramatically, becoming the largest in the United States workforce. The following are generational differences based on research by Lancaster \& Stillman (2009):

Table 1

Generational differences

\begin{tabular}{|c|c|c|c|}
\hline Factor & Body Boomers & Generation Xers & Millennial Generation \\
\hline Attitude & Optimistic & Skeptical & Realistic \\
\hline Overview & $\begin{array}{l}\text { This generation believes in } \\
\text { opportunity and is often too } \\
\text { idealistic to make positive } \\
\text { changes in the world. They are } \\
\text { also competitive and looking } \\
\text { for ways to make changes to } \\
\text { existing systems. }\end{array}$ & $\begin{array}{l}\text { The closed generation is very } \\
\text { independent and has potential, } \\
\text { not depending on other people } \\
\text { to help them }\end{array}$ & $\begin{array}{l}\text { Very respect differences, } \\
\text { prefer to cooperate rather } \\
\text { than take orders, and very } \\
\text { pragmatic when solving } \\
\text { problems }\end{array}$ \\
\hline Work Habits & $\begin{array}{l}\text { He has a high sense of } \\
\text { optimism, habits of hard } \\
\text { workers who want personal } \\
\text { appreciation, believe in } \\
\text { change and self-development }\end{array}$ & $\begin{array}{l}\text { Be aware of diversity and think } \\
\text { globally, want to balance work } \\
\text { with life, are informal, self- } \\
\text { reliant, use a practical approach } \\
\text { to work, want to have fun at } \\
\text { work, enjoy working with the } \\
\text { latest technology }\end{array}$ & $\begin{array}{l}\text { have a high sense of } \\
\text { optimism, focus on } \\
\text { achievement, self- } \\
\text { confidence, belief in mora } \\
\text { and social values, respect } \\
\text { diversity }\end{array}$ \\
\hline
\end{tabular}

Millennial identity is shaped by events such as globalization, communications, technological revival, terrorist attacks; US war in the Middle East, financial market crises, and subsequent recessions. Millennial characteristics are entitled, optimistic, civil-minded, close parental involvement, work-life balance values, impatience, multitasking, and team orientation (DeVaney, 2015). Millennials have different features compared to previous generations and include their expectations of an ideal work environment. Millennials are a dynamic, strong, and multitasking generation, who prefer to work in teams, are achievement-oriented, and want fast work progress. They seek achievement through work (Farrell \& Hurt, 2014) and contribute significantly to organizations with meaningful work. The results emerging from the analysis of interviews among groups compiled by 1000 Millennials with previous work experience, conducted by Singht et al. (2012), reveal the most common expectations of this generation. The results are summarized in the table below:

Table 2

Millennials' workplace expectations

\begin{tabular}{lll}
\hline I Would like to join for & $\mathrm{N}$ & $\%$ \\
\hline 1. A Platform to grow and actualize myself & 92 & $92,00 \%$ \\
2. Identity and Social Status & 90 & $90,00 \%$ \\
3. Opportunity to experiment and express my creativity & 88 & $88,00 \%$ \\
4. Money and Material Comfort & 60 & $60,00 \%$ \\
5. Meaningful Engagement & 58 & $58,00 \%$ \\
6. Becoming part of Community & 51 & $51,00 \%$ \\
7. Contributing to Society & 32 & $32,00 \%$ \\
8. Sense of Security and Safety & 30 & $30,00 \%$ \\
\hline
\end{tabular}

Source: Millennials' workplace expectations (Singht et al., 2012)

Manuaba, I. A. P. U., \& Darma, G. S. (2021). Examining recruitment strategies and millennial employee selection. International Research Journal of Management, IT and Social Sciences, 8(1), 110-122. https://doi.org/10.21744/irjmis.v8n1.1140 
Humans as capital or human resources are included in the company's investment process (Shick \& Palumbo, 2014). The impact of investing in human resources is to save on re-recruitment expenses, severance pay for employees who leave, and the training and education process for newly recruited employees (Shick \& Palumbo, 2014). The next influence on employees who reside in a job or company, namely employees who have the potential to be in the part occupied will provide company benefits in the form of achieving company goals (Safaat et al., 2017). Employees can be called Intangible Assets who must be trained and maintained to provide benefits to the company (Safaat, 2017). In achieving investment in human resources the company must pay attention to several factors of comfort at work and the company of an employee. Millennial's career expectations and priorities help employers to create job offers and work environments that are more likely to engage and retain millennial workers ( $\mathrm{Ng}$ et al., 2010). Based on the description above, it is necessary to research "Examining Recruitment Strategies and Selection of Millennial Employees".

Tabel 3

Characteristics of the millennial generation

\begin{tabular}{|c|c|}
\hline Author & General Millennial Characteristics \\
\hline $\begin{array}{l}\text { Feiertag \& Berge } \\
(2008)\end{array}$ & $\begin{array}{l}\text { Hypertext mindset, multi-tasking, lack of communication skills, graphic } \\
\text { orientation, expecting closeness, not responding well to lectures, requiring special } \\
\text { information, requiring technology }\end{array}$ \\
\hline $\begin{array}{l}\text { Shaw \& Fairhurst } \\
(2008)\end{array}$ & $\begin{array}{l}\text { Most are technologically literate, educated, the most ethnically religious, self- } \\
\text { confident, independent, individualistic, entrepreneurial, socially active, } \\
\text { collaborative, results-oriented, willing to work and pressure, high external locus of } \\
\text { control, high maintenance, learning value institutional, information assimilation } \\
\text { quickly, active learner }\end{array}$ \\
\hline $\begin{array}{l}\text { Meister \& Willyerd } \\
(2010)\end{array}$ & $\begin{array}{l}\text { Attention sponge, need constant feedback, rush to succeed, view work as an } \\
\text { important part of life, desire a personally satisfying life, have high expectations of } \\
\text { oneself and others, committed to community service, students with academic } \\
\text { achievements, live a mobile, collaborative, and hands-on lifestyle }\end{array}$ \\
\hline Bohl (2008) & $\begin{array}{l}\text { Passive relationship with information, wants instant gratification, expert multi- } \\
\text { tasker, will block information that looks relevant, has nothing to do with order or } \\
\text { hierarchy, wants to respect each other, strongly rejects authoritarian teaching style, } \\
\text { information collectors are perceived as independent, technology savvy, such as } \\
\text { informality, learn fast, embrace diversity, need supervision }\end{array}$ \\
\hline $\begin{array}{l}\text { Skiba \& Barton } \\
(2006)\end{array}$ & $\begin{array}{l}\text { Digital natives, fiercely independent, open about emotions and intelligence, } \\
\text { inclusive, free-to-express views (often strong views), innovative, busy with } \\
\text { maturity, investigation, desire for closeness, sensitive to the interests of others } \\
\text { (especially entrepreneurs), authentication before trust, close to parents, the value of } \\
\text { intelligence, the need for group activities, multi-tasker, first-person learning }\end{array}$ \\
\hline $\begin{array}{l}\text { Gorman, Nelson, \& } \\
\text { Glassman (2004) }\end{array}$ & $\begin{array}{l}\text { Strong written communication skills, working collaboratively, gathering } \\
\text { information quickly, sharing information easily, appreciating differences, } \\
\text { appreciating multiculturalism, resilient, easy to communicate with adults on } \\
\text { intellectual topics (unconditional), can struggle if not supervised }\end{array}$ \\
\hline $\begin{array}{l}\text { Monaco \& Martin } \\
(2007)\end{array}$ & $\begin{array}{l}\text { Lack of professional boundaries, entitlement, lack critical thinking skills, } \\
\text { unrealistic expectations, want "how-to" guidance for success, want to invest as } \\
\text { little time/effort as possible to achieve success, consider themselves special \& } \\
\text { winners, protected by parents, oriented team, confident, very optimistic, multi- } \\
\text { tasker, desire closeness, depressed, accomplished, conventional }\end{array}$ \\
\hline $\begin{array}{l}\text { Wesner \& Miller } \\
(2008)\end{array}$ & $\begin{array}{l}\text { The most educated generation equates more education with more opportunities, } \\
\text { confidence, embraces new technology, mobile, multi-tasker, does not care about } \\
\text { loyalty to an employer, achieves, wants to contribute significantly, wants a } \\
\text { meaningful job }\end{array}$ \\
\hline Donnison (2010) & $\begin{array}{l}\text { Confident, optimistic, high self-esteem, knowledgeable, experienced consumers, } \\
\text { ambitious, oriented to success, achieving goals, more confident in employability, } \\
\text { skills, and abilities, collaborative }\end{array}$ \\
\hline
\end{tabular}


Wilson \& Gerber (2008)

Elam, Stratton, \& Gibson (2007)

Glass (2007) Partridge \& Hallam (2006)
Specialized, protected, confident, team-oriented, accomplished, depressed, conventional

Hard work, extracurricular focus, generous, practical, structured, goal-oriented, assessment-oriented, team-oriented, social networking, close to parents, inhibited interpersonal skills, possible lack of critical thinking skills, respect, conventionally motivated, responsible, conscientious rule-follower, protected, protected, cooperative, mutually inclusive, high achievers, confident, optimistic Patriotic, benefited from technology, socially-minded, confident, team-oriented, structured, high self-esteem, results-oriented, constant feedback

Achievement, team-oriented, a strong emphasis on family and community, collaborative attitude, working for life - not living for work, pragmatic but optimistic, engaged, tolerant, protected, structured, looking for support, technology savvy, constant desire stimulation, valuable education, motivated, want quick answers, multi-tasker, active learning

Millennials are entering the world of work in large numbers and shaping the world of work in the long run for the future. What is attractive to millennial workers is a very important factor for the future of your business. Their career aspirations, attitudes about work, and knowledge of new technologies will change the workplace culture of the 21 st century, research has marked Millennials as tech-savvy, more technically literate and educated, and more diverse than previous generations (Eisner, 2005; Ryan\& Wessel, 2015; Papadaki et al., 2016). Eisner (2005), describes Millennials as tending to use new technology, accustomed to using several media simultaneously and continuously online, while Martin (2005), argues that close relationships with technology have even changed the way Millennials learn and process information and that they are looking for not only use technology but also use it to create their content. There is a social media use that is often done by Gen Y, namely high intensity of use, but not on their social media activities. Several studies show that Gen Y is actively contributing to content, creating, and mashing (ie combining content from multiple sources); that they gravitate toward social media sites where they can participate (Dye, 2007), and that they prefer to stay connected and multitask through technology (Rawlins et al., 2008).

On the other hand, research on students who are part of millennials shows that they spend a lot of time just consuming content (Pempek et al., 2009). In the workplace, Glass (2007), argues that millennials may prefer instant messages and emails to face-to-face conversations or phone calls. Being the first digital society in the workplace Glass (2007), shows Millennials differ from the older generation is not being afraid of new technologies. Millennials also aim to pursue a career and personal life (Martin, 2005), and expect flexible working hours to maintain work-life balance (Luscombe et al., 2013). On the other hand, Millennials are also found to be collaborative (Glass 2007), and willing to take up challenging jobs (Luscombe et al., 2013). Eisner (2005), argues that Millennials continue to look for opportunities to learn and grow professionally. Millennials value opportunities for personal development and continuous learning (Terjesen et al., 2007). There is a social media use that is often done by Gen Y, namely high intensity of use, but not on their social media activities.

Companies are increasingly realizing that they have to go beyond traditional hiring techniques to reach top millennial talent. For example, more and more companies are using social networking sites such as Facebook and YouTube to reach prospective employees, with the statistic that more than 80 percent of graduating students visit company Web sites frequently, many companies have invested in enhancing their corporate career Web pages. To attract millennials, these sites should address issues related to millennials such as work-life balance, training, and development, corporate responsibility, and diversity. To solve this problem, Web sites can include blogs, podcasts, virtual tours, and video interviews (Ron Alsop, 2008).

Recruitment is the process of determining and attracting capable applicants to work in a company. This process begins when applicants are searched and ends when applications are submitted. The result is a batch of applicants for new employee candidates to be selected and selected. Besides, recruitment can also be said to be a process to obtain several qualified human resources (employees) to occupy a position or job in a company (Rivai, 2006). Recruitment is a series of activities to find and attract job applicants with the motivation, abilities, skills, and knowledge needed to cover identified deficiencies and employment planning. Recruitment activities begin when candidates are searched for an end when their applications are submitted (Simamora, 2004). According to Rivai (2006), the purpose of recruitment is to receive as many applicants as possible following the qualifications of the company's needs from various sources, so that it is possible to recruit candidates of the highest quality of the best. The purpose of recruitment is to get as many prospective employees as possible, allowing the management (recruiter) to select or select candidates according to the

Manuaba, I. A. P. U., \& Darma, G. S. (2021). Examining recruitment strategies and millennial employee selection. International Research Journal of Management, IT and Social Sciences, 8(1), 110-122.

https://doi.org/10.21744/irjmis.v8n1.1140 
qualifications required by the company. According to Rivai (2006), the recruitment method can be divided into two, namely, internal recruitment and external recruitment. Internal sources come from the workforce currently in the company, while external sources come from people who are not currently employed by the company.

Selection is part of the operational material for human resource management which consists of planning, recruitment, selection, placement, and production. Selection is a process of specific stages used to decide which applicants will be accepted. The Selection process begins with job applicants and ends with an admission decision. The selection process is also a decision making for prospective applicants to be accepted or not (Dandy, 2015; Wooldridge, 1995; Ghodsypour \& O'Brien, 1998). Selection is a series of activity steps carried out to decide whether an applicant is accepted or rejected, in a particular institution after undergoing a series of tests carried out. Selection is also referred to as an activity of selecting and determining which applicants are accepted or rejected to become employees of the company (Rosidah, 2003; Ghosh,2016).

\section{Materials and Methods}

This research was conducted at BPR Lestari Bali, which makes continuous improvements to the recruitment and selection of millennial employees. The method used in this research is a qualitative approach with descriptive analysis methods that provide space for researchers to monitor and follow the process of recruitment, selection, and retention of millennial employees.

Collecting data using documentation techniques and structured interviews (in-depth interviews) between researchers and informants to obtain an explanation regarding the phenomenon of the problem that occurred the document review uses the data on the needs of fresh graduate employees, the overall admission report, the percentage of fresh graduates who are accepted as employees. Interviews are conducted by preparing research instruments in the form of written questions. Structured interview techniques are based on theoretical studies and a review of previously prepared documents.

Determination of informants in this study using purposive sampling technique which is based on predetermined objectives. The informants selected to answer this research question were the head of the department and human capital management staff. The data collected will then be analyzed qualitatively by data reduction, data presentation, data validity testing, and conclusion drawing. Some of the research focuses are:

The method used in the process of implementing millennial recruitment and selection

1) How is the implementation done

2) Who carries out the process of implementing the millennial recruitment and selection

3) When will the process be carried out

4) Where the process is carried out

5) What obstacles were encountered during the process of implementing millennial recruitment and selection

\section{Results and Discussions}

\subsection{Recruitment}

Table 4

Data analysis based on the results of research that has been conducted at PT. BPR Lestari Bali in the discussion of millennial generation recruitment uses the following theory

\begin{tabular}{lll}
\hline NO & The Millennial Generation recruitment method in previous research & $\begin{array}{l}\text { The recruitment method for the } \\
\text { Millennial Generation at PT. } \\
\text { BPR Lestari Bali }\end{array}$ \\
\hline 1 & $\begin{array}{l}\text { Companies are increasingly realizing that they have to go beyond } \\
\text { traditional hiring techniques to reach top millennial talent. For } \\
\text { example, more and more companies are using social networking sites } \\
\text { like Facebook and YouTube to reach out to potential employees. } \\
\text { (Mary Argue, 2015) }\end{array}$ & ALREADY APPLIED \\
\hline
\end{tabular}


2 With the statistic that more than 80 percent of graduating students visit a prospective employer's Web site frequently, many companies have invested in enhancing their corporate career Web pages. To attract millennials, these sites should address issues related to millennials such as work-life balance, training, and development, corporate responsibility, and diversity. (Ron Aslop, 2008)

3 The benefits of recruiting online for employers are reduced administrative costs, faster and no geographic restrictions. People today have a broad knowledge of what is available to them in the virtual world of job vacancies. The use of the Internet for online recruitment is becoming increasingly popular, especially with graduating students today, because it is much less time consuming, accessible, easy to use, and cost-effective. (Mary Argue, 2015)

4 Job analysis is the first step in the recruitment stage and occurs when an organization decides to fill an existing vacancy. It has a major relationship with work and employee alignment with organizational goals. These are all aspects of the recruitment and selection process and they all deserve attention, as they will impact the long-term goals of the organization. (Mary Argue, 2015)

5 Many organizations today source their employees through their universities and campuses. Doing so provides different organizations the opportunity to communicate and engage with students. (Mary Argue, 2015)

6 Many organizations today are putting more effort into engaging with universities across the country and it is more interested in recruiting graduates that recruiting graduates and internships are an important aspect of an organizational talent strategy. (Mary Argue, 2015)

$7 \quad$ Maintain an updated website: your company site should be easy to navigate and mobile-friendly and if you have posts that are timestamped (like a blog) make sure they are up to date. (Akken Cloud, 2019)

8 Create an attractive online presence (Akken Cloud, 2019)

ALREADY APPLIED

In college, Generation $\mathrm{Y}$ has the tools to get things done in a fast and efficient manner. What some might refer to as laziness, Millennials may see as efficiency. Moving from a high-tech college environment to an office that still relies on a paper filing system can be viewed as a step back. If your company doesn't adapt to new technology and sticks to inefficient methods, recruiting could go another way. Based on your budget, resources, and field, see where you can best invest in technology. (Akken Cloud, 2019)

10 Attracts millennial recruits with great company profiles (Akken Cloud, 2019)

11 Millennials emphasize their values and how they relate to their workplace. Although Generation Y is slower to marry and have children than previous generations, Millennials are looking for

ALREADY APPLIED

ALREADY APPLIED

ALREADY APPLIED

ALREADY APPLIED

ALREADY APPLIED

ALREADY APPLIED

ALREADY APPLIED

ALREADY APPLIED

Manuaba, I. A. P. U., \& Darma, G. S. (2021). Examining recruitment strategies and millennial employee selection. International Research Journal of Management, IT and Social Sciences, 8(1), 110-122. https://doi.org/10.21744/irjmis.v8n1.1140 
companies that value the values of the family around them. The Pew

Research Center found that being good parents and having a successful marriage are top priorities for Millennials. Companies that offer maternity leave and paternity and other benefits around the family will appeal to Generation Y's core value system. Additionally, Pew found helping others was the third top priority for Generation Yers. Likewise, the Intelligence Group found a priority for 64 percent of Millennials to make the world a better place. Companies can focus on being environmentally friendly, offering employees' days off to volunteer, or participating in humanitarian projects as a team to further increase attractiveness. (Akken Cloud, 2019)

Millennials are more interested in having flexible jobs that allow them to work remotely than in fancy offices (74 percent reported wanting flexible schedules). It is more important for this generation to be able to integrate their personal and professional lives. That's not to say a cool office won't help, but it takes more than just a ping-pong table to attract top talent. Additionally, companies must pay attention to how teams interact with each other - 88 percent of Millennials prefer collaborative work environments to competitive ones. The spaces where employers significantly interact - without the pressure to work for the traditional 9 to 5 days - will appeal to a generation that frequently questions traditional work methods. (Akken Cloud, 2019)

Based on the above comparisons, it can be seen that companies conducting recruitment of prospective employees require recruitment preparation, including analysis of the needs to find out the number of prospective employees needed, in what part will they be positioned, and the target of fulfilling the required employees or what is also called manpower planning. Besides that, the required preparation is the terms and conditions as well as the candidate registration procedure. After preparing for recruitment, the next activity is determining the media to disseminate information on job openings. The company has a company website that serves as a promotion about the company besides that it also has a function in recruiting employees as well. This can be seen from the "Career" menu on the website. Social media is a means to be able to interact and communicate online with potential candidates. Besides, the advantages of companies using online media in implementing recruitment are building and attracting candidates' interest because online media contains content related to the company's daily life as well as general motivational content. Social media and online media are owned by the company, namely Website Company, Facebook, Instagram, and Twitter. Besides, social media is not just promotional media; social media can be used to support the marketing strategy process in job vacancies. The content that is used and shared can also form a company brand.

Besides, the company does not only focus on recruiting new employees, but the company also opens opportunities for students who want to do internships so that the internship program will simplify the recruitment process. The internship program is a program that provides several jobs and projects to graduate students, so that internship program participants gain work experience and can experience life as a professional in their field at a company. With this internship program, companies are assisted in the recruitment process, apart from apprenticeship program participants with good evaluation results, they can work sustainably after graduating and program participants can have a positive impact on the worth of mouth process for their campus colleagues and lecturers on their respective campuses. What researchers did with informants, researchers found that the selection strategy was carried out through several selection processes, including selection through employee files, selection through focus group discussions, selection through interviews, and selection through psychological and health tests. The informant's response to selection is the process of selecting the most suitable and qualified candidate for a particular position besides that the HRD department ensures that a candidate is interested in the position offered and has the necessary qualifications and skills. The selection process helps companies to gain knowledge and abilities possessed by candidates, the candidate's self-motivation, background, and additional information that are useful for making decisions. So that the challenge in the selection process in companies is to dig up candidate information about work motivation and goals of candidates applying for jobs. 
Barriers that occur when recruitment activities are running and evaluating recruitment activities constraints usually come from prospective candidates who have difficulty registering themselves for online recruitment because they do not want to read the online form filling procedure. When a prospective candidate does not understand the registration process, the contact person listed on the web will be contacted. Based on the responses of informants regarding the obstacles or obstacles in the recruitment process, namely candidates sometimes do not know the ethical boundaries to contact both, especially the time and language used when contacting the contact person listed on the company website. Some things that happen are that prospective candidates do not understand the stages of registering via the web and do not read the registration procedure so that participants ask questions and continue to ask without wanting to find out first and potential candidates sometimes contact the contact person either by telephone or text message at night such as 22.00 up to 24.00 so that it can interfere with the contact person break hours listed on the web.

The obstacles that occur when the selection activities are running and evaluating the selection activities Constraints usually come from prospective candidates in this case, the candidates give answers about what is good about themselves, while what is not good is generally hidden. Prospective candidates are also sometimes dishonest that their desires and goals to work are only used as a temporary place to fill the time to wait for other job openings, for example, the opening of candidates for civil servants vacancies. Currently and it is estimated that by 2025,75 percent of the working population will be represented by millennials. The success of the best strategies to attract and retain millennial talent in the workplace is very important. Therefore the company must be able to pay attention to the strategies used in recruiting and selecting millennial employees.

The results of direct observation in carrying out the recruitment process, there is a pattern of changing ways, recruitment must be done from being reactive to being proactive. The process carried out in recruitment at the company is the beginning of the views of prospective employees of the company. The company has several recruitment techniques starting with the use of online media as a tool to open job vacancies and registration to follow the recruitment process at the company. Social media is a means to be able to interact and communicate online with potential candidates. Besides, the advantages of companies using online media in the implementation of recruitment are building and attracting candidates because online media contains content related to the company's daily life and general motivational content. Social media and online media owned by the company, namely Company Website, Facebook, Instagram, and Twitter The findings found that several things must be considered in posting job vacancies, one of which is the content displayed so that it can answer questions and needs of prospective candidates. Candidates will start to be interested and like the company, if what the candidate wants is what is expected. Besides, social media is not just promotional media, social media can be used to support the marketing strategy process in job vacancies. The content that is used and shared can also form a company brand.

The strategy used by the company in the recruitment process is to collaborate with well-known universities in Indonesia, in collaboration with online recruitment media such as Kalibrr and Jobstreet. The company collaborates with several campuses, namely by providing sharing sessions or presentations to students who are about to graduate and when the campus is carrying out student graduations. The company provides information about job vacancies through the websites on campus. Besides, the company does not only focus on recruiting new employees, but the company also opens opportunities for students who want to do internships or internships so that the internship program will simplify the recruitment process. The internship program is a program that provides several jobs and projects to graduate students, so that internship program participants gain work experience and can experience life as a professional in their field at a company. With this internship program, companies are helped in the recruitment process, apart from apprenticeship program participants with good evaluation results, they can work sustainably after graduating and program participants can have a positive impact on the Worth of mouth process for their campus colleagues and lecturers at their respective campuses.

Researchers also conducted interviews with informants to prospective candidates, interviews related to recruitment were carried out to 3 prospective employees who conducted recruitment through the company website. The results of the interviews with the 3 people were as follows;

The results of informant interview No.1 regarding recruitment:

"I know this company from its website and it turns out that registration is also done online and I immediately register myself. It's more efficient, no need to come to the company, anywhere I can open the website, especially if I'm from far away, my registration is faster and automatically. I complete the required data because the web process forces us to fulfill the file documentation requirements"

Result of the interview with informant No.2 regarding recruitment:

Manuaba, I. A. P. U., \& Darma, G. S. (2021). Examining recruitment strategies and millennial employee selection. International Research Journal of Management, IT and Social Sciences, 8(1), 110-122.

https://doi.org/10.21744/irjmis.v8n1.1140 
"In the area where I live, the company is already quite famous with many young people who have careers and work there, my school friends also work there a lot, then I also dig up information on company activities through its Instagram and website, besides that, I have also met on Kalibrr that the company currently opening job vacancies " The results of the interview with informant No.3 regarding recruitment:

"Previously I had done an apprenticeship program in a company with many of my friends, so I was interested in working in the company because during my internship at the company I knew enough about the positive values and culture of the company for me".

\subsection{Selection}

Table 5

Data analysis based on the results of research that has been conducted at PT. BPR Lestari Bali in the discussion of the millennial generation selection process strategy uses the following theory

\begin{tabular}{|c|c|c|}
\hline NO & The Millennial Generation selection method in previous research & $\begin{array}{l}\text { The recruitment method for } \\
\text { Millennial Generation in the } \\
\text { research of PT. BPR Lestari Bali }\end{array}$ \\
\hline 1 & $\begin{array}{l}\text { Make them an offer they can't refuse. Career concern top career } \\
\text { issues: } \\
\text { - Financial Security }(33 \%) \\
\text { - Job Stability }(26 \%) \\
\text { - Career Satisfaction }(23 \%) \\
\quad \text { www.hotjobs.com }\end{array}$ & ALREADY APPLIED \\
\hline
\end{tabular}

2 As the demand for talented young people continues to grow, businesses must develop creative recruiting techniques. Some recruiters use video and video games to attract potential talent. Others use strategy games and contests to identify potential employees. Others read messages on career-oriented message boards, access online bank resumes, and host online career fairs to reach out to this technologically connected generation. However, as Alsop notes, "The days of the students who win and eat are not over." In addition to recruiting virtually, companies should continue to invite a select number of candidates for face-to-face interviews to assess their suitability for the organization. (Ron Aslop, 2008)

3 We learned from the Crash Course of Recruiting Graduates (2011, p.19) that Accenture provides a boot camp where candidates can meet with consultants to discuss what a career involves with the organization. It leaves a lasting impression on a candidate and shows how an organization can make an impact through something so simple. There is a lot of competition in graduate recruitment today because many organizations are looking for the best employees (Mary Argue, 2015)

4 Fostering a creative and collaborative work environment (www.akkencloud.com)

ALREADY APPLIED

ALREADY APPLIED

5 Make them Offers they can't refuse. Career Concern, Top Career Problems:

- Financial Security

- Job Stability

- Career Satisfaction 
(www.hotjobs.com)

6

Provides informatio

Generation such as:

- Health service coverage

- Paid vacations

- Dental care coverage

- Bonuses

(www.hotjobs.com)

7

Show them how they can grow. (www.hotjobs.com)

8

Special messages for potential candidates. HR managers need to send a clear message to potential candidates, highlighting three main factors: job responsibilities, reasons for choosing them as candidates, and salary ranges (Abbot, 2015)

Differentiation factors. To attract potential employees, employers need to demonstrate that the company is competing with competitors, offering higher compensation, professional development, and more opportunities for advancement.

10

Positive interview experience. According to Abbot (2015), interviewing experience, including having all questions answered and receiving feedback, consistently influences Millennials in considering job offers. $73 \%$ of Millennials say they feel comfortable following up with potential employers after the interview
ALREADY APPLIED

ALREADY APPLIED

ALREADY APPLIED

ALREADY APPLIED

ALREADY APPLIED

Based on the above comparison, it can be seen that several selection process strategies, namely the employee file selection process, the company selects files with several provisions, namely the completeness and clarity of the candidate files. Files that are registered online by candidates must comply with the terms and conditions contained in the online media for candidate registration. Some of the advantages that can be assessed from a candidate are activeness in English, active use of social media, achievements of the candidate, and the candidate's latest education.

In the selection process through Focus Group Discussion, the company gathered several candidates who were gathered and put into one class, which was accompanied by 2 interviewers. In the Focus Group Discussion class, the company starts the class with an introduction to the Company Profile. After that, the forum opens to ask questions and answers about the company by candidates and interviewers.

The Focus group Discussion also involved candidate participants to do Games organized by the recruitment committee. In this game, companies can see the participant's leadership, enthusiasm, initiative, and participants' way of thinking. This game invites and attracts candidates to show energy for the fun of the candidates. The company also explains that the company's vision and mission is the attraction of employees to work in a company. Working at a company that is still developing and has a good vision and mission provides many career opportunities for employees. The activities published by the company also dance sports activities, CSR activities, promotional activities, and company work environment activities. The education and employee development provided by the company supports the quality and career process for the better. The company has a coaching system for new employees and employees who are looking to develop their careers. In addition to this coaching system, leaders in the company can serve as mentors for employees who want to develop their potential. Sharing sessions about employees who have served are often held to motivate employees to achieve their respective careers.

Selection through Interview Human Capital Management conducted direct interviews with candidates who had passed the selection through Focus Group Discussion. Candidates will be interviewed with several questions related to their family background, educational background, previous work background/history, assessing the candidate's enthusiasm, how much they understand the company being applied for, and several things related to the candidate's psychology.

Manuaba, I. A. P. U., \& Darma, G. S. (2021). Examining recruitment strategies and millennial employee selection. International Research Journal of Management, IT and Social Sciences, 8(1), 110-122.

https://doi.org/10.21744/irjmis.v8n1.1140 
Then the selection stage is through direct interviews by the Compliance Director with candidates who have passed the selection through interviews by HCM. In this interview session, nothing was too specific to ask, just to convince the candidate whether he was really interested in joining the company. Selection through the psychological test is carried out by the psychological test; the psychological test is carried out in collaboration with the company. Some of the things that are assessed from this psychological test are thinking ability, workability, socio-emotional ability, and individual potential.

Selection through the Medical Check-Up Test is carried out by the collaborating company, namely PT. Quantum Medical Means. Some of the examination points used as a reference for the candidates' tests are Urinalysis, Hematology, X-rays, Kidney, Liver, Blood Sugar, Heart, and Fat. At the stages of company selection, notification of graduation information or not will be given via email to participants. This is intended so that participants do not feel confused about the results of their selection process, reduce participant complaints about the company selection process, and make it easier for companies to communicate with participants. The author conducts an interview process with prospective candidates who are following the selection process; the results of interviews with 3 prospective employees who are currently participating in the selection process are as follows:

The results of the No.1 informant interview related to selection:

"I was currently participating in the selection process in the Focus Group Discussion section; I was very excited to follow the process. During the Focus Group Discussion there we discussed what we want from the company and what the company wants from its employees"

The results of informant interview No.2 related to the selection process:

"I was following the selection process in the interview section of the directors, I felt challenged when I was interviewed by the directors because I have a hobby of sports and I am challenged to run $3-5 \mathrm{~km}$, and I can show that I can and I am interested in the opportunity. And challenges like that so I feel challenged"

Informant interview results from No.3 related to selection:

"The selection process carried out by the company is very professional because the system uses email if each stage of the selection succeeds or fails, I failed at the psychological stage but I want to try again, maybe I'm lacking in the numeric section"

\section{Conclusion}

From the research results based on the information obtained, it can be concluded that the recruitment and selection processes have been good in implementation. The recruitment strategy can be carried out in various ways, both using online media, social media, collaboration with well-known campuses, through online recruitment media, and an internship program. In addition to the media used, companies must also be able to pay attention to the media content so that it can attract the attention of candidates who are looking for work. It is very important to note the explanation of the selection stage process to candidates, conveying information on success or failure to the next stage is very important for prospective candidates. Besides, the selection process is very important to do both during the Focus Group Discussion process and the interview process, because during this process companies and candidates can unite their perceptions of what the company and the candidate expect. So that there will be no disputes in the future because the rules and regulations of the company are not clear and good information is not delivered. Researchers are aware of the limitations possessed by researchers, further research is expected to be carried out in several different locations. In addition to different locations, it is hoped that the next research can examine employee retention. this is to be able to evaluate what factors are related to a company's retention strategy.

\section{Conflict of interest statement}

The authors declared that they have no competing interests.

\section{Statement of authorship}

The authors have a responsibility for the conception and design of the study. The authors have approved the final article.

\section{Acknowledgments}

We are grateful to two anonymous reviewers for their valuable comments on the earlier version of this paper. 


\section{References}

Alsop, R. (2008). The trophy kids grow up: How the millennial generation is shaking up the workplace. John Wiley \& Sons.

Argue, M. (2015). The importance of the strategic recruitment and selection process on meeting an organisations objectives (Doctoral dissertation, Dublin Business School).

Dandy, P. D. (2015). The Process of Recruitment, Selection, and Placement of New Workers at PT Jasa Raharja Malang.

Deal, J. J., Altman, D. G., \& Rogelberg, S. G. (2010). Millennials at work: What we know and what we need to do (if anything). Journal of Business and Psychology, 25(2), 191-199.

DeVaney, S. (2015). Understanding the Millennials. Journal of Financial Services Professional Data, (4) 11-14.

DiBiase, R. A., Whipple, K. X., Heimsath, A. M., \& Ouimet, W. B. (2010). Landscape form and millennial erosion rates in the San Gabriel Mountains, CA. Earth and Planetary Science Letters, 289(1-2), 134-144. https://doi.org/10.1016/j.epsl.2009.10.036

Dye, J. (2007). Meet Generation C: Creatively Connecting Through Content-Generation C is the" You" in YouTube, the" My" in MySpace, and the" i" in iPod. They're you (and me), and they're shaking up the way people. EContentDigital Content Strategies and Resources, 30(4), 38-43.

Eisner, S. P. (2005). Managing generation Y. SAM Advanced Management Journal, 70(4), 4.

Farrell, L., \& Hurt, A. C. (2014). Training the millennial generation: implications for organizational climate. E Journal of Organizational Learning \& Leadership, 12(1).

Ghodsypour, S. H., \& O'Brien, C. (1998). A decision support system for supplier selection using an integrated analytic hierarchy process and linear programming. International journal of production economics, 56, 199-212. https://doi.org/10.1016/S0925-5273(97)00009-1

Ghosh, C. (2016). The evaluation of new marketing strategy of selected home appliances. International research journal of management, IT and social sciences, 3(11), 33-38.

Glass, A. (2007). Understanding generational differences for competitive success. Industrial and commercial training .

Koe, W. L., Sa'ari, J. R., Majid, I. A., \& Ismail, K. (2012). Determinants of entrepreneurial intention among millennial generation. Procedia-Social and Behavioral Sciences, 40, 197-208. https://doi.org/10.1016/j.sbspro.2012.03.181 https://doi.org/10.1016/j.sbspro.2012.03.181

Lancaster, L. C., \& Stillman, D. (2009). When generations collide: Who they are. Why they clash. How to solve the generational puzzle at work. Harper Collins.

Luscombe, J., Lewis, I., \& Biggs, H. C. (2013). Essential elements for recruitment and retention: Generation Y. Education+ Training.

Martin, C. A. (2005). From high maintenance to high productivity. Industrial and commercial training.

Ng, E. S., Schweitzer, L., \& Lyons, S. T. (2010). New generation, great expectations: A field study of the millennial generation. Journal of business and psychology, 25(2), 281-292.

Papadaki, A., Thanasoulias, A., Pound, R., Sebire, S. J., \& Jago, R. (2016). Employees' Expectations of Internet-Based, Workplace Interventions Promoting the Mediterranean Diet: A Qualitative Study. Journal of nutrition education and behavior, 48(10), 706-715. https://doi.org/10.1016/j.jneb.2016.08.003

Pempek, T. A., Yermolayeva, Y. A., \& Calvert, S. L. (2009). College students' social networking experiences on Facebook. Journal of applied developmental psychology, 30(3), 227-238. https://doi.org/10.1016/j.appdev.2008.12.010

Rawlins, J. M., Simeon, D. T., Ramdath, D. D., \& Chadee, D. D. (2008). The elderly in Trinidad: Health, social and economic status and issues of loneliness. West Indian Medical Journal, 57(6).

Rivai, V. (2006). Human Resource Management for Companies: from Theory to Practice. PT. Raja Grafindo Persada, Jakarta.

Rosidah, A. T. S. (2003). Manajemen Sumber Daya Manusia. Cetakan Pertama. Penerbit Graha Ilmu. Yogyakarta.

Ryan, A. M., \& Wessel, J. L. (2015). Implications of a changing workforce and workplace for justice perceptions and expectations. Human Resource Management Review, 25(2), 162-175. https://doi.org/10.1016/j.hrmr.2015.01.001

Safaat, M. A., Widiarto, A. E., \& Suroso, F. L. (2017). Pola Penafsiran Konstitusi dalam Putusan Mahkamah Konstitusi Periode 2003-2008 dan 2009-2013. Jurnal Konstitusi, 14(2), 234-261.

Shick, R. A., \& Palumbo, G. (2014). Life-Time Earnings by Age and Level of Education. BRC Journal of Advances in Business, 2(1), 1-11.

Simamora, H. (2004). Manajemen Sumber Daya Manusia Edisi III. Jakarta: STIE YKPN.

Manuaba, I. A. P. U., \& Darma, G. S. (2021). Examining recruitment strategies and millennial employee selection. International Research Journal of Management, IT and Social Sciences, 8(1), 110-122.

https://doi.org/10.21744/irjmis.v8n1.1140 
Singh, P., Bhandarker, A., \& Rai, S. (2012). Millennials and the workplace: Challenges for architecting the organizations of tomorrow. SAGE Publications India.

Terjesen, S., Vinnicombe, S., \& Freeman, C. (2007). Attracting generation Y graduates. Career Development International.

Wooldridge, J. M. (1995). Selection corrections for panel data models under conditional mean independence assumptions. Journal of econometrics, 68(1), 115-132. https://doi.org/10.1016/0304-4076(94)01645-G 